\title{
Conclusion
}

\section{Toward an Understanding of Erotics}

It is looking more and more as if the model of (homo) sexuality with which I grew up, and whose genealogy I have tried to map ... never had more than a narrowly circumscribed reach. That model never succeeded for very long in establishing a concept or a practice of sexuality wholly defined by sexual object-choice (same sex or different sex) to the exclusion of considerations of gender identity, gender presentation, gender performance, sexual role, and social difference. It never completely decoupled sexuality from matters of gender conformity or gender deviance, from questions of masculinity and femininity, activity or passivity, dominance and submission, from issues of age, social class, status, wealth, race, ethnicity, or nationality. And canons of homosexuality and heterosexuality in their turn installed their own norms of gender identity and sexual role, while seeming to insist with breathtaking categorical simplicity on the "sameness" or "difference" of the sexes of the sexual partners. It turns out that such notions of sameness or difference contained their own hidden stipulations about the condition under which members of the same sex could really be considered the "same," or had to be 
classed, despite the sameness of their sexes, as actually "different."

-David Halperin, How to Do the History of Homosexuality

In this eight-minute short, a museum guard, a middle-aged man of African descent played by Thomas Baptiste and referred to in the credits only as the Attendant, has a sexual encounter with a white man played by John Wilson, called the Visitor. Their attraction to one another takes place in relation to F.A. Biard's 1855 abolitionist painting "Slaves on the West Coast of Africa" which is displayed in the museum. This painting, the film's first image, shows a slave market. There, a white, presumably European man straddles a prone, presumably African man, as other black and white men look on or continue their business. In the periphery of this scene, more white men whip, bind, inspect, and brand other black men. During an ordinary day on the job, the Attendant meets the seductive gaze of the Visitor, and the Biard painting suddenly and literally comes alive. It metamorphoses into a tableau vivant of an interracial sexual orgy, with the participants posed exactly as they were on the canvas, only now wearing modern SM gear. After the museum finally closes, the Attendant and the Visitor consummate their lust by whipping one another in a room off the main gallery — or the Attendant may simply imagine this happening, the film leaves this ambiguous.

—Elizabeth Freeman, on Isaac Julien's short film The Attendant

What makes sex sexy? To begin to answer that question, I have suggested that the concept of the fetish provides an essential 
beginning - an idea that originated, as we have seen, in the contact zone of Atlantic Africa, centuries ago. Tastes beyond rationality, attractions that operate like external controlling organs of the postmodern body, fetishes are contextual and can coexist, sometimes in contradictory ways, and they can change, sometimes dramatically, more often in a person's younger years, but occasionally later as well. And-perhaps most importantly, as in SM-fetishes can be cultivated as tastes can be "educated." They depend upon an infrastructure of mediation, social interaction, and historical context.

The discourse on the fetish is a part of a much larger conversation in social theory about how persons and things interact, an exchange that includes, besides Marx and Freud, Marcel Mauss's famous account of the gift, and into the present, Bruno Latour's (2005, 20I0) formulations of actor network theory. All of these approaches problematize, in different ways, the assumed boundaries of persons and things, or persons and parts of persons treated like things. These processes, in the present case, created passions so strong that they propelled bodies halfway around the globe, altering the material contexts of other bodies in ways perhaps impossible to imagine otherwise. ${ }^{\prime}$

Here, sexual fetishes became parts of scripts for fantasies that aroused bodies to sexual excitement. According to John Gagnon and William Simon's pioneering 1973 book Sexual Conduct, such scripts occur on at least three levels: that of the internal psychic reality of an individual, in scripts for social interaction between two or more individuals, and finally with respect to cultural scenarios that recur across social contexts. After the Internet, sexual actors have explicitly labeled their intrapsychic fantasies as "fetishes," inviting others to participate in social interaction, typically drawing on wider cultural narratives. 
In 1979, psychoanalyst Robert Stoller began his book Sexual Excitement with the following playfully tedious paragraph:

It has surprised me recently to find almost no professional literature discussing why a person becomes sexually excited. There are, of course, innumerable studies that have to do with that tantalizingly vague word "sexuality": studies on the biology of reproduction, masculinity and femininity, gender roles, exotic beliefs, mythology, sexuality in the arts, legal issues, civil rights, definitions, diagnoses, aberrations, psychodynamics, changing treatment techniques, contraception, abortion, life-styles, transsexual operations, freeranging and experimental animal behavior, motoro, pornography, shifts in age of menarche and loss of virginity, masturbatory rates, research methodology, bride prices, exogamy, incest in monkeys and man, transducers, seducers, couvade, genetics, endocrinology, existentialism, and religion. Statistical studies of the external genitals, foreplay, afterplay, accompanying activity, duration, size, speed, distance, metric weight, and nautical miles. Venereal disease, apertures, pregnancy, berdaches, morals, marriage customs, subincision, medical ethics, sexism, racism, feminism, communism, and priapism. Sikkim, Sweden, Polynesia, Melanesia, Micronesia, Indonesia, and all the tribes of Africa and Araby. Buttocks, balls, breasts, blood supplies, nervous supplies, hypothalamic supplies, gross national product, pheromones, implants, plateaus, biting, squeezing, rubbing, swinging. Nude and clothed, here and there, outlets and inlets, large and small, up and down, in and out. But not sexual excitement. Strange. (Stoller 1979, I)

A decade and a half later, sociologist William Simon (1996, 23) wrote, "Beyond the work of Stoller and relatively few others, the question of what creates sexual excitement, how it is rooted not in our bodies but in our lives, has only been considered in the most superficial ways." Now, after yet more timeduring a period in which we have seen a veritable explosion of work on so-called sexualities, as well as the creation of a new 
interdisciplinary field called queer theory-I'm not convinced that we know a lot more about comparative erotics. Strange.

The explanation of this lack is no doubt complex. Shame continues to play some part. But I have suggested that another reason is conceptual: however free-floating the idea of sexuality has become, it inevitably retains a central assumption that object choice trumps all other aspects of what makes sex sexy. In this way, it obscures the range of the erotic.

The seeming simplicity and obviousness of gender create a bright light effect that either obscures other dimensions of object choice or establishes the gender of the object as the encompassing distinction that renders all other attributes subordinate... The most one can say about the dominance of gender in eliciting sexual interest or excitement is that it is a minimal precondition for most individuals most of the time, and even then not necessarily for the same reasons. The issues of age, race, physical appearance, social status, quality and history of relationship and the specifics of context, among other attributes, also play roles as compelling, if not more so, than that played by gender. (Simon 1996, 34-35)

I have suggested that we attempt to build another approach to the erotic in which the sex and gender of an object choice is seen as only another fetish - among many, many others. If there are master fetishes, this fact will only be established by an approach that does not begin with the answer it expects - and by so doing participates, itself, in the creation of "sexuality."

What made extraverted sex erotic to Africans was hardly its object (some were looking explicitly for either male or female foreign partners) but that it allowed an expansion of personhood via participation in a cosmopolitan world from which colonialism had previously excluded them. It also, ironically, allowed for the continuance of local kin groups. It was almost as if the erotic 
aroused not just the individual body but also the social body. And, of course, the "acceptance" by the ghetto itself was crucial in lessening pressures against a practice that otherwise might have drawn condemnation.

On the other side of the interaction, the white men who found their way to Africa were hardly simply "homosexuals," though they fit that category more easily than their African counterparts, and most saw themselves in such terms. They were attracted not just by any man, nor indeed by any black man. There was an element of surrender to the foreign involved, an elevation of the erotic by a degree of danger, and perhaps an aspect of enjoyable masochism-all protected by the power of a foreign passport.

Stoller provides a significantly revised version of the sexual fetish in relation to Freud:

Let us take fetishization as the key process in the creation of erotic excitement. We might best begin by calling it dehumanization; the fetish stands for a human (not just, as is sometimes said, for a missing penis). A sexually exciting fetish, we know, may be an inanimate object, a living but not human object, a part of a human body (in rare cases even of one's own), an attribute of a human (this is a bit less sure, since we cannot hold an attribute in hand), or even a whole human not perceived as himself or herself but rather as an abstraction, such as a representative of a group rather than a person in his or her own right ("all women are bitches"; "all men are pigs"). The word "dehumanization" does not signify that the human attributes are completely removed, but just that they are reduced, letting the fetish still remind its owner of the original human connection, now repressed. As a result the same move (like a seesaw) that dehumanizes the human endows the fetish with a human quality. (Stoller 1979, 7)

The more agency attributed to a fetish, the less to the original human agent who wounded. Part of Stoller's insight involves an 
appreciation of the essential element of hostility. "(l) A person who has harmed one is to be punished with a similar trauma. (2) The object is stripped of its humanity. (3) A nonhuman object ... is endowed with the humanness stolen from the person on whom one is to be revenged. In this way the human is dehumanized and the nonhuman humanized. (4) The fetish is chosen because it has some quality that resembles the loved, needed, traumatizing object" (Stoller 1979, 8).

But hostility can be intertwined with love: "With it [the mechanism of fetishization] one focuses on and overvalues a part without fully taking in the whole. That in itself need not, however, rule out affection. Rather than keeping two people at a distance from each other, it could be a device that, by increasing the other's erotic attractiveness, promotes closeness, enriches love" (Stoller 1979, 33).

Stoller's book, an extended account of the analysis of a woman he calls Belle, is devoted to intrapsychic conflicts. Nonetheless, as I have argued, it should provoke us to consider the other social and cultural levels at which sexual scripts are written.

Once we have constructed this approach to erotics, it is altogether striking to observe the current lopsidedness of knowledge. We know virtually nothing about the erotics of those who ostensibly do not deviate from the cultural norm, that is, the unmarked category, in the West, of straight people (see Katz 1995). That blank space arguably allows the continuing mythologization of heterosexuality.

Just as studies of race began with black people and turned to whites, and just as studies of gender started with females and moved to males, studies of the erotic need to move beyond the margins to include hegemonic forms of eroticism. I predict we are in for some surprises. 
Let me consider how the approach to erotics I have been advocating differs from a focus on sexualities. Let me take up, in turn, space, time, and media.

Space. A sexuality is a state of being, and as such, it easily maps onto a picture of the world as a mosaic of differently colored, mostly internally homogeneous cultures separated by clear boundaries. Ancient Greek sexuality. Modern North American sexuality. Brazilian sexuality.

Like Ruth Benedict in The Chrysanthemum and the Sword, the analyst of sexualities typically oscillates back and forth between "us" and "them" (Geertz I988) to make a thousand comparisons that finally illuminate both "them" and "us." Think of David Halperin's (1990) distinguished work on ancient Greece, One Hundred Years of Homosexuality.

The erotic sets up no such pressures to assume homogeneous cultural spaces (see Sedgwick 1990). The contact zone I have depicted was for centuries a blurred transitional zone between different colors on the map, an exception in a world in which the default situation was thought to be cultural homogeneity. After the Internet, the contact zone has spread out from a smudged boundary to represent something much closer to the default situation in our postmodern world.

Do not stable forms of interaction with respect to something as central as sex require shared meanings? This essay illustrates why the answer is no. Alfred Chester (1990), an American gay man writing about Paul Bowles's Tangiers, used the metaphor of a glory hole to capture the contact zone in Morocco. A glory hole, in gay terminology, is an aperture bored through a partition between stalls in a public restroom that allows for anonymous sexual intercourse. The communicating hole connects, but the partition continues to separate. 
If continued interaction across cultural boundaries can eventually replace glory holes with more multidimensional interaction, in the short term the effect can be otherwise. In the ghetto described here, I would argue that the contact zone set in motion processes that depended precisely upon the maintenance-not the blurring-of cultural and linguistic boundaries. Except for Johnny, no gay white man in the ghetto, to my knowledge, learned much of the local African language.

To illustrate what I mean, consider the question of why African men were not feminized, in their own minds, by a situation in which gay Europeans were economically providing for their wives and children. Husbands do not support wives in West Africa in the same way they did at a certain point in Western history, but in patrilineal societies husbands are expected to help support children. According to this African cultural logic, why did European support for African children not threaten the masculinity of African men?

Such assuredly did not happen. It was, rather, the Europeans who were feminized by Africans, and, just like African women, they were subjected to a double standard when it came to sexual propriety. An African man might have multiple sexual partners and might have secret partners on the side (and indeed either of these could be celebrated in the right context), but if a European man attempted to do the same in Africa, he put himself in real danger and was, at the very least, morally condemned. He was a "butterfly," someone who randomly sipped from flower to flower.

So how did African men remain so male in their own terms? I would suggest that a large part of the answer rests on the fact that the two partners came from different cultural backgrounds. In a sense, this is simply a requirement of extraversion itself: an actor may "trick" outside his reference group but 
not inside it. If both partners were African, then the one who was supported might well have felt the pressures of feminization. For the one who was doing the supporting would have known the requisite codes, the devastating small asides, for feminizing another. This might explain the relative lack in the ghetto of eroticization of other African men, even wealthy African men.

Outside the neighborhood on which I am reporting, there were, apparently, secret underground networks of African men who had sex with other African men. According to one of the older men I interviewed in the ghetto, these relationships were focused on shrine priests of traditional religion. Same-sex sex, he contended, was the "secret" that generated the power of traditional religion.

It is interesting to note that the role of same-sex sex in African-derived religions in the New World has long been realized (Landes 1940) but that until recently, its presence on the African side has been almost totally ignored. Recently, Matory (2003) has called attention to the way that traditional spirit possession is culturally constructed in Yoruba religion. The spirit "mounts" his devotee just as a rider mounts a horse or a man sexually mounts a woman.

Imagine my surprise when I made the acquaintance of a highly respected Yoruba art historian from Oyo, whose extended family included many Sango priests in that West African cultural capital. During his time among oricha-worshippers in the United States, this scholar too became aware of the importance of men who love men in the New World priesthoods. Without having read my work, he had concluded that male-male sexual conduct among New World priests was a continuation rather than a mere reinterpretation of West African religious traditions. He told me that, on two occasions between 1968 and 1973, he witnessed possessed male 
Sango priests anally penetrate unpossessed male priests in an Oyo shrine. He does not know, however, if this practice was widespread or whether it represented a tradition or norm. Nor do I. (Matory 2003, 424)

Gay slang has long labeled the scene that Matory describes as "running a train": a deity mounts a possessed devotee, who, at the same time, mounts an unpossessed devotee. If sexual "fluidity" was a particular aspect of the ghetto, it was perhaps not absent from the wider Atlantic African cultural scene. But unlike the relationships between African and foreign men, African-African relationships were apparently closely kept secrets.

Differences in sexual cultures do not, then, necessarily mean social instability. Consider the love triangles of each of the cases I have mentioned-von Gloeden in Sicily, Bowles in Tangiers, Johnny in Atlantic Africa. The European men who successfully negotiated the contact zone in these cases did so through their "management" of love triangles. They related, in a way, to both their male lovers and their lovers' wives (and children). Triangles stabilized social interaction.

Von Gloeden kept individual accounts for each photographic image of a nude Sicilian boy he sold, and he provided royalties to the young man himself - which helped the latter marry a local woman. Bowles translated the stories of his loversstories about love triangles, in fact-so that they earned their own royalties. And finally, Johnny established with Justice (by then married to a second wife) a business in the ghetto that for a time created considerable support for Justice's family and, more widely, local employment.

In literary theory, there has been a long meditation on erotic triangles, the subject, after all, of countless European novels and short stories. This consideration begins (if not with Freud's 
Oedipal scene of a child and a mother and father) with René Girard's description, in Deceit, Desire, and the Novel, of what he called mimetic desire-desire for a beloved provoked not only by the beloved but by a reaction to a rival's desire: two men attracted to the same woman. In Between Men, Eve Sedgwick took the argument further to examine the nature of the relationship between the two men, the creation of "homosociality," sometimes as a defense against "homosexuality." Finally, Terry Castle followed in The Apparitional Lesbian to analyze two women and one man, and Marjorie Garber attempted to ring all the triangular changes of gender and sexual attraction in Bisexuality and the Eroticism of Everyday Life. Much of the insight of this extended conversation stems from its attempts to place erotic incitement in the context of social relationality, across sexual types, not just within them.

Time. Because sexuality, unlike erotics, is figured primarily in relation to consciously held identity and therefore to political struggles, historical accounts of change in sexuality have a strong tendency to become either narratives of progress, of the past leading up to the present, or of narratives of increasing subjection (these two being mirror images of one another).

George Chauncey's work on gay marriage is a distinguished and perhaps necessary example of the first. Michel Foucault's (to retranslate the title) The Will to Know: The History of Sexuality, Vol. $I$, is an impressive example of the second.

To follow Foucault's thought further for a moment, notice that the way he uses the notion of sexuality has little to do with sexual excitement. Indeed, in what is probably the most questionable move that Foucault makes in The History of Sexuality, Vol. I, he claims that the West-unlike ancient India and Japan, for example-did not have an ars erotica, an art of cultivating the erotic. 
"Sexuality," then, is fundamentally a matter of discourse in the context of social and political institutions, what Foucault called a dispositif, a device or apparatus (Halperin 1995). According to Foucault, the sexologists who thought of themselves as "discovering" homosexuality had actually created it in some senses. Ian Hacking (1984, I22) called this type of argument dynamic nominalism: "Categories of people come into existence at the same time as kinds of people come into being to fit those categories, and there is a two-way interaction between these processes." As this process works itself out, discourses in the context of social devices insert the hold of biopower ever more insidiously into acting individuals.

A turn toward erotics helps free analysis from these lines of increase or decrease. Without too much distortion, one could say that - in the imagination at least - not all that much changed over the centuries in the Atlantic African case I have depicted. What the Internet (re)created was simply the contact zone of previous centuries in which men from substantially different cultural points of view interacted. It is now the very idea of "sexuality" - that Europeans and Africans are alike "gay"that functions as a fetish, just like the African ritual objects on which European and African traders took oaths centuries ago. In other words, sexuality represents now the "creative misunderstanding" that allows European-African social interaction. A certain "trade" continues, one concerned still with "gold" and sometimes even "slaves."

Media. Sexuality, since it is assumed to be a state of being, a state that emanates from inside a person and that is, in fact, "discovered," does not invite questions about the role of media. In a wide-ranging study, Robert Paul (2015) has recently attempted to theorize cultural transmission per se. According to Paul, it 
always takes place with respect to sensory reality outside individual human beings, with language being perhaps the "first" such channel:

... the effective life of symbols occurs in their transmission into and through the medium of the sensory world, in the realm of things seen, heard, smelled, tasted, felt, and experienced. By virtue of being transmitted this way, rather than via copulation, symbols, unlike genes, can be perceived by and can inform many people at once, and thereby produce a sense of kinship among groups that is real in the same sense that genetic kinship is real: that is, it describes the relationship of people whose behavior is informed by the same instructions. (Paul 2015, 285)

It is far easier to pose the question of how sexual fetishes are communicated once one turns from the rubric of sexuality. Waugh points out that both homosexuality and photography were created at about the same time and have been intertwined ever since. Waugh $(1996,32)$ suggests that the circulation of photographs played something of the same role in shaping communities of same-sex erotics as print capitalism did with regard to nationalisms (Benedict Anderson's well-known argument). These processes are not yet fully understood. "The picture does not create desire," Simon (1996, I42) cautions, "desire creates the picture. The picture evokes desire, but only the desire that was lying in wait." One wonders whether further analysis will not grant more "agency" to images.

In any case, because of what Bazin called the "ontology" of photographs, their presumed unmediated ability not just to capture reality but to be real, it is clear that photographic images have an elective affinity with fetishes. And as Metz (1985) argued, because the viewer of a photograph (as opposed to a film, for example) can choose the length of time he or she gazes, 
photographs have the unique ability to imprint themselves on viewers. Finally, photographs viewed on a computer screen connected to the Internet add yet another layer of specificity, of assumed secrecy across wide dissemination with a shielding from public shame.

Now reproduced at virtually no cost via the span and reach of the Internet, which extends now to areas of the world like the ghetto, photographs and films have created a massive new encyclopedia of erotic reference (Escoffier 2007) - much of it beyond states' attempts to control so-called pornography. This new form of mediation allows for an explicit mobilization of erotic fetishes to an unprecedented degree and so helps to produce ever more specialized and splintered erotic communities.

As a final matter, I want to speculate on how fetisheseconomic and erotic-interrelate in late capitalism. Let me note, first, that money may be the single object under capitalism that functions both as an economic fetish (the way it is seen misrepresents and thus preserves economic domination) and, curiously, as an erotic fetish (its contemplation can sexually arouse). Besides the materials presented here, Gregory Mitchell's (2016, 77) work on Brazilian male prostitutes who have sex with men furnishes an example: "To keep himself focused, he has the mantra that he tells himself: I want to have this money. He focuses on the money, fantasizing about cash to keep himself stimulated during the programa."

As Gayle Rubin points out in the epigraph to this book, many erotic fetishes such as latex, vinyl, and silk stockings depend upon historically particular industrial processes. They reflect a specific, capitalist history. At a deeper level, any form of power contains a kind of wounding - a dehumanization, if you will-continually recollected in both individual and collective 
memory. That connection is perhaps more widely appreciated in psychoanalytic approaches to the individual, but it is present as well at larger scales in both colonialism and capitalism. If Stoller, Gagnon, and Simon are correct, both colonialism and capitalism have produced their characteristic forms of erotic fetishes.

At first glance, one might assume that SM plays with and eroticizes the forms of domination found in wider society. But SM's interrelationship with capitalism is more complex than this. Indeed, it is striking, from what I can tell, that the domination of capitalists over workers is typically not eroticized. Why? In contrast to so-called precapitalist modes of production that name and naturalize their forms of inequality (whether that enjoyed by fathers or chiefs or feudal lords), the culture of capitalism insists that it has no domination. Workers and capitalists are formal equals. Each enters into a "free" contract. Workers sell their labor power. And capitalists buy it. In volume i of Capital, it took Marx literally hundreds of pages to demonstrate the illusion of such freedom and equality — an illusion created, Marx argued, by the fetishization of capital, the idea that money (not the labor of workers) makes money. Money can also sexually arouse, but capitalist domination itself (which is, to the degree possible, erased) cannot.

Capitalism presents itself, then, as a narrative of freedom, of a progressive removal of all previous forms of "bound" labor. But since Eric Williams's Capitalism and Slavery (1944), if not since Marx's own Capital, volume I, we have known that things are hardly so simple. In some real sense, the Atlantic slave trade was created by global capitalism. After an extended and epic struggle in the nineteenth century, slavery was finally repudiated and capitalism purified to depend primarily on "free" wage labor. But then, the newly magnified shame of slavery helped 
to construct the increasingly unquestionable freedom of capitalism. The more shameful slavery became, the more ethically secured and egalitarian capitalism appeared.

The relation between shame and labor was thus exactly reversed compared to precapitalist modes of production. In the latter, selling labor was what was shameful - that is, waged labor itself. Labor could be ethically transacted only by gifting it or by embedding it in relationships to kin or chiefs or lords (Donham [1985] 1994).

According to Tomkins, it is precisely shame that is the key affect in intrapsychic scripts of SM, the practitioners of which he calls the "daredevils of shame":

If an individual is haunted with a chronic sense of shame for sexual exploration, then the idea of power becomes necessarily tied to the violation of the constraints that originated the taboo. We have found abundant clinical evidence that under such conditions sexual excitement requires an exaggerated shamelessness or power to undo, reverse, and deny the power of the other to evoke shame for one's own sexuality. Such a one therefore becomes excited primarily by fantasies in which he, or the other, or both indulge in the most flagrant indecencies or humiliations and in which there is a reveling in shame. Other variants we have analyzed ... include elaborate fantasies of omnipotence in which the sexual partner is a slave or a captive. (Tomkins $1995,73^{-74}$ )

So SM plays with not the actual system of domination in capitalism but its dark shadow, which, since the nineteenth century, has accompanied and defined it by contrast. 4

In this project, it was often the details that spoke the loudest to me. Johnny once laughingly told me that when he moved from Oakland to Atlantic Africa, he had packed chains. According to African American artist Kara Walker, "Everyone wants to play 
the nigger now." Strategic overstatement, no doubt. But applied to the fantasies of some gay white men in Atlantic Africa, Walker's art brilliantly captures the layered, moving, and sometimes surprising nature of the erotic - a topic we scholars have hardly begun to explore. 